\title{
Variability in the Growth of Faidherbia albida: The Soils Connection
}

\author{
S. C. Geiger, ${ }^{*}$ R. J. Vandenbeldt, and A. Manu
}

\begin{abstract}
Variability in the growth of Faidherbia albida (Del.) A. Chev. (syn. Acacia albida [Del.]) in the Sahelian zone of West Africa is a common observation. The "albida effect" has been attributed to the amelioration of soil chemical, physical, and microbiological properties by the direct action of the tree, resulting in enhanced crop production beneath the mature canopy. Crop yields within fields without $F$. albida can also be highly variable within short distances. A study was conducted to observe the association between the variability in soil properties and the variable growth of young (2-yr-old) $F$. albida trees planted at the ICRISAT Sahelian Center located near Niamey, Niger. The results of this study indicate that the variability in $F$. albida growth is caused, in large part, by variability in soil properties across relatively short distances. Good growth sites had higher clay contents and base saturations, and lower exchangeable acidity than poor growth sites within the field. The tallest trees in the field were associated with the proximity to abandoned termite mounds and other microhigh sites. Seedlings planted on sheet-eroded sites caused by runoff from microtopographical high sites within the field grew poorly. The variability in $F$. albida growth in plantations within Niger is hypothesized to be due, in part, to preexisting soil conditions. These results also suggest that the albida effect might be partially caused by these preexisting "islands of fertility". This site-determined variable growth of $F$. albida could be exploited with proper seedling placement strategies.
\end{abstract}

\footnotetext{
$F$
} AIDHERBIA ALBIDA is a leguminous tree species found in most semiarid regions of Africa. Its native range resembles a large crescent, extending from Senegal to Ethiopia, then to the Limpopo River system in South Africa and finally west to Namibia and Angola. In the Sudano-Sahelian zone of West Africa, it is an important part of traditional parkland cropping systems (Vandenbeldt, 1990). Although not a consistent phenomenon, the species is renowned for the socalled "albida effect", i.e., crops growing under mature $F$. albida have higher yields than crops growing away from the tree canopy. Dancette and Poulain (1969), for example, found a twofold increase in sorghum [Sorghum bicolor (L.) Moench] and a 30\% increase in groundnut (Arachis hypogaea L.) yields when grown under the tree canopies. Charreau (1974)

S.C. Geiger, K.W. Brown Environmental Services, 1005 West Ninth Avenue, Suite A, King of Prussia, PA 19406; A. Manu, TropSoils/Dep. of Soil and Crop Sciences, Texas A\&M Univ., College Station, TX 77843; and R.J. Vandenbeldt, International Crops Research Institute for the Semi-arid Tropics (ICRISAT), B.P. 12404, Niamey, Niger. Submitted as journal article no.1144, ICRISAT, Niamey, Niger. Received 21 June 1991. *Corresponding author.

Published in Soil Sci. Soc. Am. J. 58:227-231 (1994). and Poschen (1986) have reported similar results for pearl millet [Pennisetum glaucum (L.) R. Br.] and maize (Zea mays L.).

A primary reason for this yield increase could be the curious reverse phenology of the species. Typically, $F$. albida retains its leaves through the long Sahelian dry season, and begins a defoliation phase coinciding with the onset of rains in May and June. This light shading early in the growing season, in conjunction with the noncompetitive rooting habit of the species, provides a conducive microclimate to crops developing underneath the canopy (ICRISAT Sahelian Center, 1990). Refoliation occurs in October to November, at the end of the rainy season and after crop harvest.

In addition, many authors explain the improved crop yields under $F$. albida by a "nutrient pump" model, where symbiotically fixed $\mathrm{N}$ and assimilated soil nutrients are cycled to the soil surface through litter fall (Centre Technique Forestier Tropical, 1988). It is well known that soils under the mature tree canopy generally have better fertility conditions than adjacent soils. Dancette and Poulain (1969) found a $40 \%$ increase in organic $\mathrm{C}$ and $\mathrm{N}$ and moderate increases in exchangeable $\mathrm{Ca}$ under the mature canopy in comparison to surrounding soils. Charreau and Vidal (1965) noted similar increases in $\mathrm{C}$ and $\mathrm{N}$, a $50 \%$ increase in cationexchange capacity (CEC), a $25 \%$ increase in base saturation, and modest increases in clay and silt contents. Jung (1966) found 52\% higher clay contents, a $120 \%$ increase in CEC, and a $100 \%$ increase in $\mathrm{C}$ and $\mathrm{N}$ in his study on soil microbiology under $F$. albida. This increase in soil fertility has also been attributed to the addition of feces and urine from livestock rested by herders under the trees during the hot hours of dryseason days.

There have been many attempts to plant $F$. albida in farmers' fields to increase total system productivity and therefore crop yield. These, however, have met with mixed results, primarily because of erratic tree establishment and subsequent variable growth. For example, in a 100-ha plantation in Abala, Niger, the height of neighboring, surviving trees at $15 \mathrm{yr}$ of age ranged from 1 to $20 \mathrm{~m}$ (R.J. Vandenbeldt, 1990, unpublished data). Several authors have attributed the variability in the growth of $F$. albida to genetic heterogeneity (Felker, 1978).

Patterns of this variable tree growth are similar in appearance to variable millet growth caused by shortrange spatial variability in soil physical and chemical 


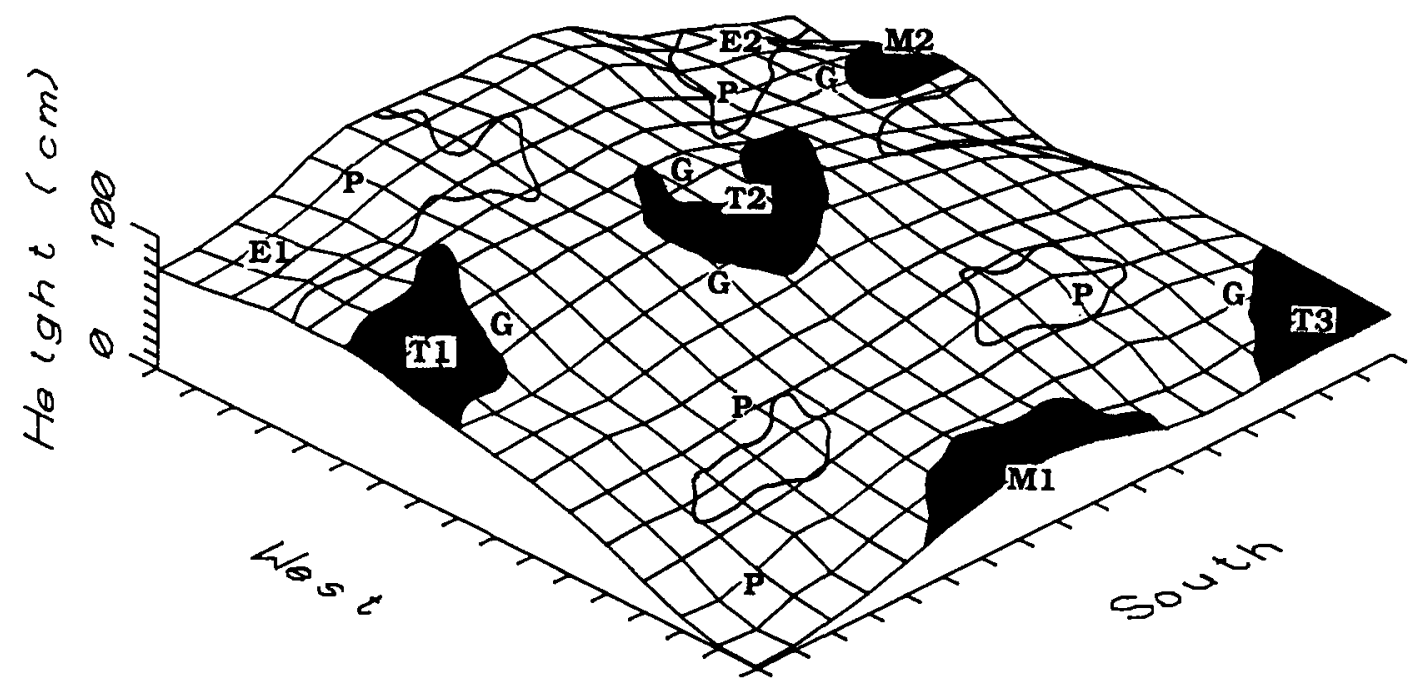

Fig. 1. Relative surface elevation within the field: $M 1$ and $M 2$ are microtopographic highs; T1, T2, and T3 are abandoned termite mounds; and E1 and E2 are sheet-eroded sites. Soil sampling sites are labeled as $P$ (poor) and $G$ (good) growth sites. The shaded spots are areas where tree height was $>140 \mathrm{~cm}$. The circled spots are areas where tree height was $<90 \mathrm{~cm}$.

properties in the Sahelian zone of West Africa (Pfordresher et al., 1989; Manu et al., 1990). Generally, the most productive sites within cultivated fields are associated with microtopographic high positions, and the most unproductive sites are associated with slightly lower erosional surfaces. The productive sites are characterized by lower $\mathrm{Al}$ saturation, higher base saturation, and a thicker $A$ horizon. A field can change from very productive to nonproductive within a range of 5 to $15 \mathrm{~m}$ as a result of these "islands of fertility".

Several of the soil properties measured under mature $F$. albida canopies, especially the $52 \%$ increase in clay contents reported by Jung (1966), cannot be explained by the nutrient pump or any other currently proposed hypothesis. Quantitative experiments to determine whether increased soil productivity precedes trees in similar agroforestry systems or is, in fact, created by the presence of trees, do not exist (Sanchez, 1987). If, indeed, the survivability and growth of $F$. albida is dependent on better microsites, then it could be logically argued that such fertility would remain later in the life of the tree and influence the increased crop growth underneath it.

The objectives of this study were to examine the spatial relationship between soil properties and $F$. albida growth in a plot representative of local Sahelian conditions. This information will be used to aid agroforesters in the design of outplanting strategies, and also to contribute to the scientific knowledge concerning the cause and effect of $F$. albida on site enrichment.

\section{MATERIALS AND METHODS}

\section{Site Description}

The experiment was located at the ICRISAT Sahelian Center, Sadore, Niger, $45 \mathrm{~km}$ south of Niamey at $13^{\circ} \mathrm{N} 2^{\circ} \mathrm{E}$. The field is situated within the sand plain geomorphological unit, which consists of gentle sloping terraces of eolian sand underlain by an indurated laterite layer. At this particular field, the laterite layer occurs at a depth of approximately $5 \mathrm{~m}$. The soil within this field is part of the Labucheri series and is classified as a sandy, siliceous, isohyperthermic Psammentic Paleustalf according to the U.S. soil taxonomy (West et al., 1984). Total yearly rainfall averages approximately $540 \mathrm{~mm} /$ yr. Depth to the water table is approximately $30 \mathrm{~m}$.

The trial was planted in August 1987, using 3-mo-old potted seedlings raised from a bulked collection of seeds from 20 trees growing near Sadore. Seedlings were transplanted in a 2 by $2 \mathrm{~m}$ grid pattern that covered an area of $5305 \mathrm{~m}^{2}$ with a final population of 1258 trees. This trial was originally intended to determine the effects on seedling survivability of a water-retentive gel and low levels of $P$ fertilizer placed in the seedling root zone at planting. There was no effect of either treatment on seedling survivability or growth, and the trial was subsequently abandoned. Three years after planting, our study was initiated as a result of the observation that a high degree of spatial variability of tree growth was evident within the field.

\section{Field Methodology}

Soil topographic differences throughout the field were measured using standard survey equipment. Relative elevational readings were collected on a 4 by $4 \mathrm{~m}$ grid, with each sample location located equidistant from four adjacent trees. In March $1990, F$. albida growth was estimated by measuring plant height. Heights of the four trees surrounding each topographic grid point were used to derive average tree height corresponding to each elevational datum.

Since the study was imposed on a preexisting field, it concentrated on soil properties between and within groups of good and poor tree growth as observed in the field. Five sites were located in areas of poor tree growth, and five sites were located in areas of good tree growth. Soils were sampled to a depth of $150 \mathrm{~cm}$ in $10-\mathrm{cm}$ increments at each site with the use of a bucket auger.

The highest and lowest points in the field differed by 125 $\mathrm{cm}$ in relative elevation (Fig. 1). The highest surface was found in the north-central area of the field, with elevation decreasing generally to the corners. The lowest surface was located in the southwest corner. The field, therefore, was situated on a large topographic high surrounded by topographic low positions. The eroded remnants of three termite mounds (T1, $\mathrm{T} 2$, and $\mathrm{T} 3$ in Fig. 1) were found within the field. These are generally characterized by a slightly raised crusted surface of approximately 2- to 3-m diameter, which in themselves constitute small microtopographic high sites. One of the termite mounds (T2) was 
located in the middle of the dominant microtopographic high in the center of the field. In addition, two small microtopographic high sites of $\approx 2-$ to $3-\mathrm{m}$ diameter were found in the field (M1 and $M 2$ in Fig. 1). These were not associated with old termite mounds, at least from the surface of the soil. The termite mounds and microtopographic highs occurred on a smaller scale than the elevation data recorded for the topographic survey, which was comprised of 4-m spacings between measurement points. Two large surfaces showing the effects of sheet erosion were observed in the northeast and northwest portion of the field (E1 and E2 in Fig. 1). These surfaces were created by surface runoff from the dominant high point in the center of the field.

\section{Soil Analyses}

All soil samples were air dried and ground to pass through a 2-mm sieve prior to analysis. Particle-size distribution was determined by the pipette method (Gee and Bauder, 1986). Soil $\mathrm{pH}$ was measured in 2:1 soil/water and $1 \mathrm{M} \mathrm{KCl}$. Exchangeable acidity and $\mathrm{Al}$ were determined by titration after extraction in $1 M \mathrm{MCl}$ as described by McLean (1982). Exchangeable bases were displaced with $1 \mathrm{M} \mathrm{NH}_{4} \mathrm{OAc}(\mathrm{pH} 7.0$; Thomas, 1982). Calcium and $\mathrm{Mg}$ were analyzed with atomic absorption spectrophotometry, and $\mathrm{K}$ and $\mathrm{Na}$ by flame photometry. Organic $\mathrm{C}$ was determined by the wet oxidation method of Walkley and Black (Nelson and Sommers, 1982). Available $P$ was determined by the Bray-1 extraction procedure, and $P$ in solution was analyzed spectrometrically using the molybdate blue method (Olsen and Sommers, 1982).

Data obtained from the good-growth sites were compared with that obtained from the poor growth sites through the calculation of standard errors.

\section{RESULTS}

\section{Relationship between Microtopography and Tree Growth}

Tree height ranged between 44 and $209 \mathrm{~cm}(\mathrm{CV}=$ $26.0 \%$ ). The CV among the trees located in the five good-growth sites was $12.3 \%$, identical to that of the five poor-growth sites. This indicated that genetic heterogeneity was unlikely to be the cause of the variable growth pattern. The tallest trees were found at the southwestern edge of the dominant topographic high position, which is located approximately in the center of the field and at the location of T2. Tree height generally decreased from this central area in all directions, except for other islands of superior growth shown in Fig. 1.

The correlation between tree growth and surface topography for the entire field was nonsignificant. While average tree height was dramatically different between the good- and poor-growth sites selected for their growth characteristics, average surface topographical differences of these sites relative to the entire field were not (Fig. 2). These data indicate that factors other than those associated with large-scale relief characteristics were primarily responsible for the variable growth (i.e., the variability existed on a smaller scale than evidenced from the gross surface topography of the entire field). The best tree growth occurred on the localized microtopographic high positions and at the termite mounds (Table 1). Tree heights in these areas were among the highest $25 \%$ found in the field. Tree growth was poor in the center of each termite mound, but was the highest in the field immediately surrounding the crusted surface of the center part of the mound. None of the poor-growth sites were associated with a microtopographic high position.

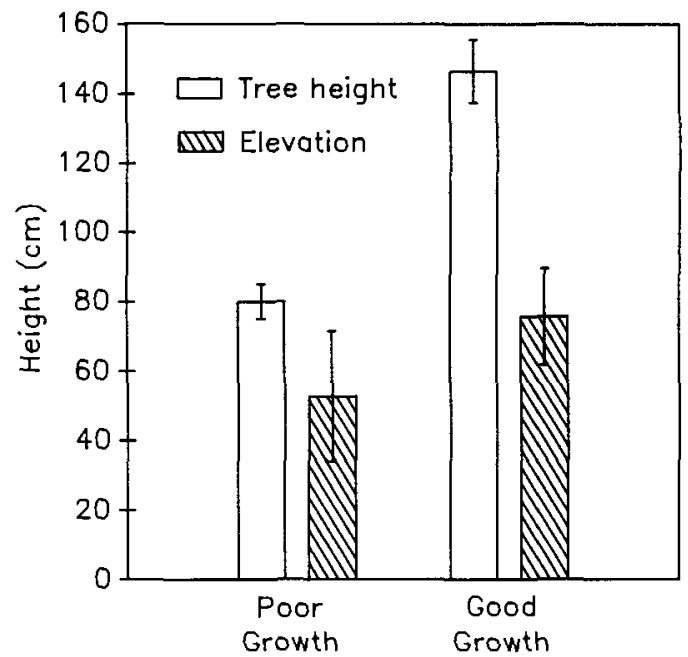

Fig. 2. Average tree height and relative surface elevation associated with good- arit poor-growth sites. Vertical bars represent one standard error.

The poorest tree growth was observed in the two erosional areas of the field (Table 1).

\section{Soil Characteristics Associated with Good- and Poor-Growth Sites}

Average clay contents in the good- and poor-growth sites (Fig. 3) were similar to a depth of 20 to $30 \mathrm{~cm}$, but diverged below the $30-\mathrm{cm}$ depth. The greatest difference was at the $150-\mathrm{cm}$ depth. The general trend indicated a clear increased clay content with depth in the good-growth sites. Total exchangeable bases were similar to a depth of $20 \mathrm{~cm}$, and then diverged below this depth, following the trend in clay distribution (Fig 3). Exchangeable acidity was greater at the poor-growth sites below a depth of $40 \mathrm{~cm}$ (Fig. 3). This result is in line with the exchangeable bases data, and with the fact that the variability in millet growth in this part of the Sahel is negatively correlated with exchangeable acidity (Scott-Wendt et al., 1986). Values of available $P$, although different between good and poor sites, were too close numerically to allow a definitive conclusion to be drawn (Fig. 3). These soils are generally deficient in available $\mathrm{P}$ with respect to crop growth. However, it is not clear at this time if the Bray$1 \mathrm{P}$ test is selective enough to discriminate between the marginally P-sufficient and -deficient soils of this region.

\section{DISCUSSION}

Soil parameters affecting the fertility status, to a depth of $150 \mathrm{~cm}$, were different between the good- and poor-

Table 1. Tree heights associated with the abandoned termite mounds (T1, T2, and T3), microtopographic highs (M1 and M2), and erosional surfaces (E1 and E2) within the field.

\begin{tabular}{lcccc}
\hline Microsite & $\begin{array}{c}\text { Microsite } \\
\text { code }\end{array}$ & Tree height & $\begin{array}{c}\text { Standard } \\
\text { error }\end{array}$ & Trees \\
\hline & & cm & & no. \\
Termite mound & T1 & 152 & 14 & 16 \\
& T2 & 147 & 29 & 16 \\
Microhigh & T3 & 161 & 9 & 16 \\
Erosional surface & M1 & 176 & 7 & 6 \\
Field average & E1 & 138 & 8 & 6 \\
& E2 & 69 & 15 & 81 \\
& & 108 & 28 & 1258 \\
\hline
\end{tabular}



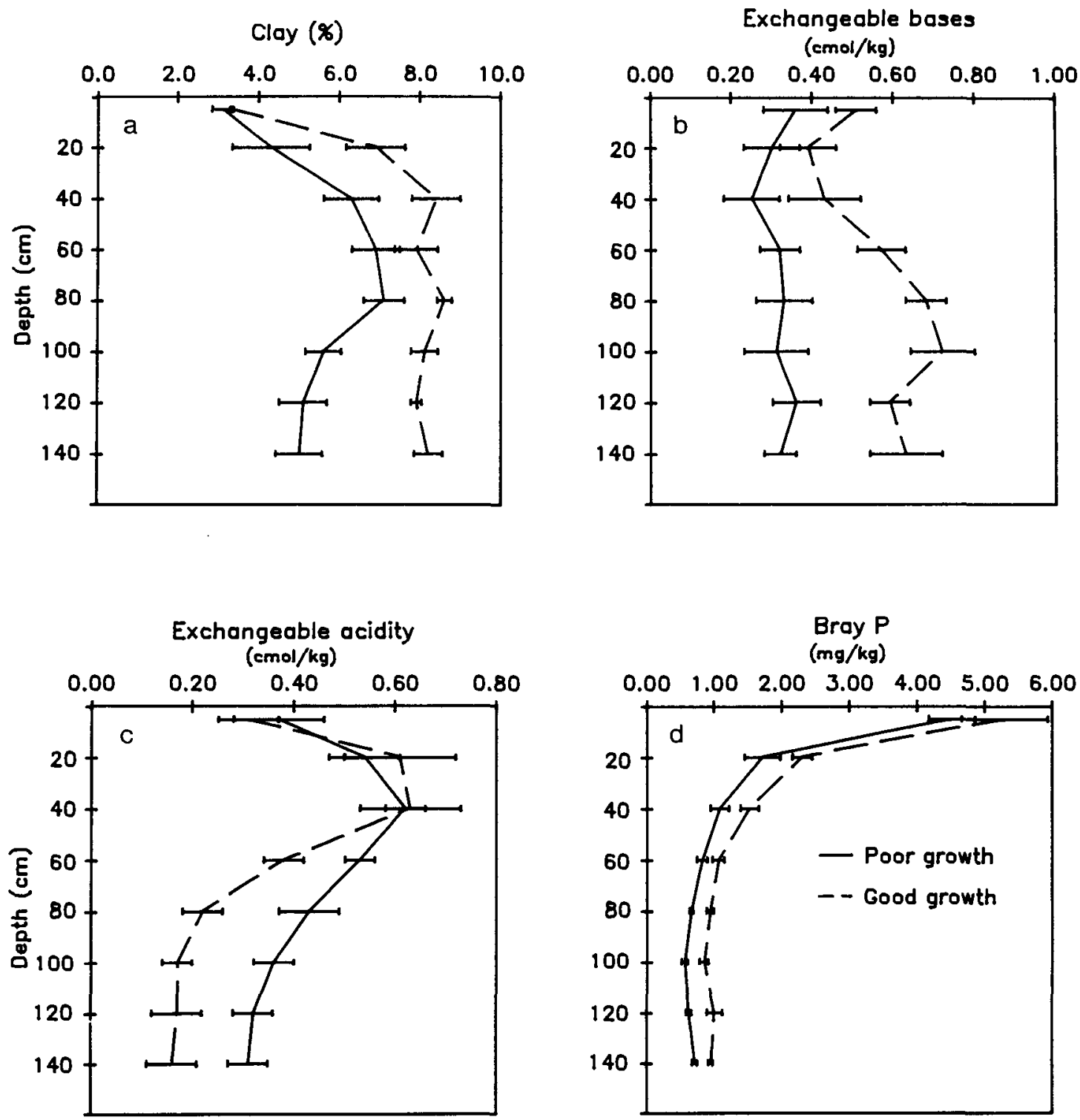

Fig. 3. Physical and chemical properties of soils in the good- and poor-growth sites: (a) clay distribution, (b) exchangeable base distribution, (c) exchangeable acidity distribution, and (d) distribution of Bray-1 P. Horizontal bars represent one standard error.

growth sites. The most striking differences were in clay content and exchangeable acidity, which effectively control the status of other fertility parameters in these poorly buffered soils. Tree height was greater in the good-growth sites than the poor-growth sites. Tree height was also greater in microhigh areas, including those surrounding abandoned termite mounds, and poorer in areas showing the effects of sheet erosion. From these observations, it can be concluded that there is an association between the factors responsible for microtopographic variability and the growth of $F$. albida within this field site.

An association between abandoned termite mounds and increased growth of crop plants has been observed in the Sahel (Lal, 1987). In the termite mounds within the field, this effect could be attributed to two factors: (i) water harvesting from the surface of the mound, where rain falling on the crusted surface runs off and is concentrated in the surrounding soil, and (ii) increased fertility status or water-holding capacity of the soils beneath the mound due to an enrichment in clay. It is likely that the increased clay contents in the good-growth sites associated with abandoned termite mounds, which were only different from the clay contents in the poor sites below a depth of 20 to $30 \mathrm{~cm}$, were due to the action of termites in the redistribution of high-clay-containing soils from below the indurated laterite layer to the surface $2 \mathrm{~m}$. To take this one step further, the existence of microtopographic highs supporting good tree growth may possibly be due to the presence of very old termite mounds, which are no longer visible at the soil surface, as a result of the reworking of the fragile soil surface by eolian forces prevalent in the Sahel. The action of termites in reworking the soil could also have resulted in the increased fertility status of these sites.

Previous studies relating soil variability with pearl millet growth variability have shown a clear relationship with microtopographic position (Pfordresher et al., 1989; Geiger et al., 1992). However, differences in soil phys- 
ical and chemical parameters were greatest in the top 20 to $30 \mathrm{~cm}$ of those soils, and relatively similar below that depth. This type of variability has been associated with deposition and deflation of eolian materials and is different from the variability described in this study. Since $F$. albida rapidly establishes a root zone below the surface soil horizon, it is not expected that differences in the top 20 to $30 \mathrm{~cm}$ of these soils would have a great effect on tree growth after the initial establishment of the tree.

In the "real world", $F$. albida is established by natural regeneration through livestock seed dispersal (manure). Mortality caused by browsing and weeding activities is high. If one assumes that seed is randomly dispersed in fields through animal manure, then it follows that the fastest growth and highest survival will be by those seeds landing on the most productive microsites on the landscape. The high productivity found under the resulting mature trees could therefore be partly due to the preexisting fertility of the microsites.

It is likely that the growth variability found in $F$. albida plantations in Niger is caused by similar trends. A suitable method of control of this problem would be to restrict tree planting to the better sites, i.e., adjacent to termite mounds, microhighs, and other "islands of fertility". This would tend to ensure the greatest tree survivability and maximum productivity of both the trees and the crops grown beneath the canopies. At the same time, the fertility of these microsites would be sustained and even improved through other factors integrated in the albida effect.

Further studies are being conducted to ascertain the relationship between the growth of young (establishing) and old (established) $F$. albida trees and measurable soil parameters.

\section{ACKNOWLEDGMENTS}

This research was supported, in part, by Grant no. DAN1311-G-SS-1083-00 of the U.S. Agency for International Development (USAID).

\section{REFERENCES}

Centre Technique Forestier Tropical. 1988. Faidherbia albida (Del.) A. Chev. (Synonyme: Acacia albida Del.). Monographie. Centre Technique Forestier Tropical, Nogent-sur-Marne, France.

Charreau, C. 1974. Soils of tropical dry and dry-wet climatic areas of West Africa and their use and management. Agron. Dep. Mimeo 74-26. Cornell Univ., Ithaca, NY.

Charreau, C., and P. Vidal. 1965. Influence de l'Acacia albida
Del. sur le sol, nutrition minrale et rendements des mils Pennisetum au Senegal. Agron. Trop. 6-7:660-626.

Dancette, C., and J.F. Poulain. 1969. Influence of Acacia albida on pedoclimatic factors and crop yields. African Soils 14:143184.

Felker, P. 1978. State of the art: Acacia albida as a complementary permanent intercrop with annual crops. Grant no. AID/afrC-1361. USAID, Washington, DC.

Gee, G.W., and J.W. Bauder. 1986. Particle-size analysis. p. 383-412. In A. Klute (ed.) Methods of soil analysis. Part 1. 2nd ed. Agron. Monogr. 9. ASA and SSSA, Madison, WI.

Geiger, S.C., A. Manu, and A. Bationo. 1992. Changes in a sandy sahelian soil following crop residue and fertilizer additions. Soil Sci. Soc. Am. J. 56:172-177.

ICRISAT Sahelian Center. 1990. West African annual report. ICRISAT Sahelian Center, Niamey, Niger.

Jung, G. 1966. Etude de l'influence de l'Acacia albida (Del.) sur les processus microbiologiques dans le sol et sur leur variations saisonnires. Centre ORSTOM, Dakar, Senegal.

Lal, R. 1987. Termites. p. 337-421. In R. Lal (ed.) Tropical ecology and physical edaphology. John Wiley \& Sons, Chichester, England.

Manu, A., S.C. Geiger, A. Berrada, and J.W. Scott-Wendt. 1990. Microvariabilit dans le Sahel: Un aperu gnral. p. 117-128. In Actes du Sminaire sur l'Amnagement des Sols, la Conservation de l'Eau et la Fertilisation, Tahoua. 20-24 fvrier 1989. Institute National de Recherches Agronomiques du Niger (INRAN), Niamey, Niger.

McLean, E.O. 1982. Soil pH and lime requirement. p. 199-224. In A.L. Page et al. (ed.) Methods of soil analysis. Part 2. 2nd ed. Agron. Monogr. 9. ASA and SSSA, Madison, WI.

Nelson, D.W., and L.E. Sommers. 1982. Total carbon, organic carbon and organic matter. p. 539-582. In A.L. Page et al. (ed.) Methods of soil analysis. Part 2. 2nd ed. Agron. Monogr. 9. ASA and SSSA, Madison, WI.

Olsen, S.R., and L.E. Sommers. 1982. Phosphorus. p. 403-430. In A.L. Page et al. (ed.) Methods of soil analysis. Part 2. 2nd ed. Agron. Monogr. 9. ASA and SSSA, Madison, WI.

Pfordresher, A.A., L.P. Wilding, L.R. Hossner, A. Manu, S.C. Geiger, and R.C. Maggio. 1989. Application of infrared video imagery to evaluate crop spatial variability in the Sahel, West Africa. TropSoils Tech. Rep. Dep. of Soil and Crop Sciences, Texas A\&M Univ., College Station.

Poschen, P. 1986. An evaluation of the Acacia albida-based agroforestry practices in the Hararghe highlands of eastern Ethiopia. Agrofor. Sys. 4:129-143.

Sanchez, P.A. 1987. Soil productivity and sustainability in agroforestry systems. p. 205-223. In H.A. Steppler and P.K.R. Nair (ed.) Agroforestry: A decade of development. ICRAF, Nairobi, Kenya.

Scott-Wendt, J., R.G. Chase, and L.R. Hossner. 1986. Soil chemical variability in sandy Ustalfs in semiarid Niger, West Africa. Soil Sci. 145:414-419.

Thomas, G.W. 1982. Exchangeable cations. p. 159-166. In A.L. Page et al. (ed.) Methods of soil analysis. Part 2. 2nd ed. Agron. Monogr. 9. ASA and SSSA, Madison, WI.

Vandenbeldt, R.J. 1990. Agroforestry in the semiarid tropics. p. 150-194. In K.G. MacDicken and N.T. Vergara (ed. Agroforestry: Classification and management. John Wiley \& Sons, New York.

West, L.T., L.P. Wilding, J.K. Landeck, and F.G. Calhoun. 1984. Soil Survey of the ICRISAT Sahelian Center, Niger, West Africa. Texas A\&M Univ./TropSoils, College Station. 